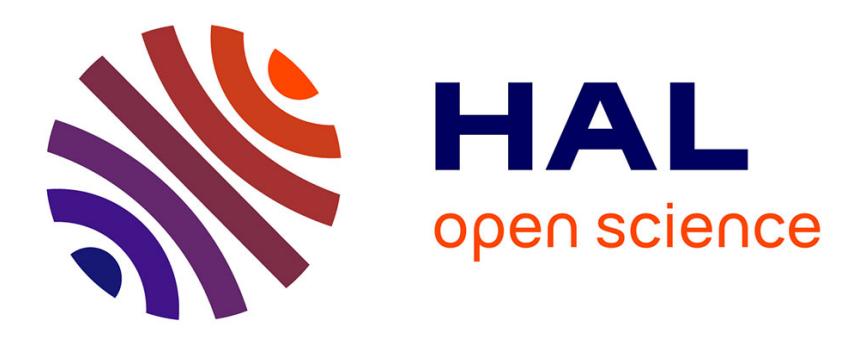

\title{
Angiogenesis and development of adipose tissue
}

\author{
V. Christiaens, H.R. Lijnen
}

\section{To cite this version:}

V. Christiaens, H.R. Lijnen. Angiogenesis and development of adipose tissue. Molecular and Cellular Endocrinology, 2010, 318 (1-2), pp.2. 10.1016/j.mce.2009.08.006 . hal-00567232

\section{HAL Id: hal-00567232 \\ https://hal.science/hal-00567232}

Submitted on 19 Feb 2011

HAL is a multi-disciplinary open access archive for the deposit and dissemination of scientific research documents, whether they are published or not. The documents may come from teaching and research institutions in France or abroad, or from public or private research centers.
L'archive ouverte pluridisciplinaire HAL, est destinée au dépôt et à la diffusion de documents scientifiques de niveau recherche, publiés ou non, émanant des établissements d'enseignement et de recherche français ou étrangers, des laboratoires publics ou privés. 


\section{Accepted Manuscript}

Title: Angiogenesis and development of adipose tissue

Authors: V. Christiaens, H.R. Lijnen

PII:

DOI:

S0303-7207(09)00410-9

Reference: doi:10.1016/j.mce.2009.08.006

MCE 7287

To appear in: $\quad$ Molecular and Cellular Endocrinology

Received date: 27-5-2009

Revised date: 27-7-2009

Accepted date: $\quad$ 7-8-2009

Please cite this article as: Christiaens, V., Lijnen, H.R., Angiogenesis and development of adipose tissue, Molecular and Cellular Endocrinology (2008), doi:10.1016/j.mce.2009.08.006

This is a PDF file of an unedited manuscript that has been accepted for publication. As a service to our customers we are providing this early version of the manuscript. The manuscript will undergo copyediting, typesetting, and review of the resulting proof before it is published in its final form. Please note that during the production process errors may be discovered which could affect the content, and all legal disclaimers that apply to the journal pertain. 


\title{
Angiogenesis and development of adipose tissue
}

\author{
V. Christiaens, H.R. Lijnen \\ Center for Molecular and Vascular Biology, KU Leuven, Leuven, Belgium
}

Address for correspondence: H.R. Lijnen

Center for Molecular and Vascular Biology

KU Leuven, Campus Gasthuisberg, O \& N 1,

Herestraat 49, Box 911, 3000 Leuven, Belgium

Tel 32-16-345771

Fax 32-16-345990

e-mail: roger.lijnen@med.kuleuven.be 
Keywords: obesity, angiogenesis, adipocytes, endothelial cells, blood vessels

\begin{abstract}
Obesity is a common disorder and related diseases, such as diabetes, atherosclerosis, hypertension, cardiovascular disease and cancer, are a major cause of mortality and morbidity in Western-type societies. Development of obesity is associated with substantial modulation of adipose tissue structure. The plasticity of the adipose tissue is reflected by its remarkable ability to expand or to reduce in size throughout adult lifespan. The expansion of adipose tissue is linked to the development of its vasculature. Indeed, adipogenesis is tightly associated with angiogenesis, as shown by the findings that adipose tissue explants trigger blood vessel formation, whereas in turn adipose tissue endothelial cells promote pre-adipocyte differentiation. Different components have been identified that play a role in adipose tissue associated angiogenesis. Modulation of angiogenesis may have the potential to impair adipose tissue development and thus may provide a novel therapeutic approach for prevention and treatment of obesity.
\end{abstract}




\section{Introduction}

Over the last decades obesity and its consequences worldwide have become a major health problem. Between 1976 and 2002, the prevalence of overweight (body mass index $(B M I) \geq 25 \mathrm{~kg} / \mathrm{m}^{2}$ ) in the United States has increased from $46 \%$ to $66 \%$ of the population, and that of obesity (BMI $\geq 30 \mathrm{~kg} / \mathrm{m}^{2}$ ) from $15 \%$ to $31 \%$ (Hedley et al., 2004). Excess weight increases the risk of multiple conditions, including hypertension, cardiovascular and cerebrovascular disease, type 2 diabetes, certain types of cancer, respiratory diseases, gallstones and osteoarthritis. Obesity is frequently associated with metabolic abnormalities such as impaired glucose tolerance, hyperinsulinemia, dyslipidemia with elevated triglyceride level, decreased high-density lipoprotein cholesterol concentration and increased proportion of small dense lipoparticles. This cluster of metabolic disturbances is called the metabolic syndrome, and represents known risk factors for cardiovascular disease. In addition, obesity negatively affects physical functioning, vitality, and general quality of life (Kopelman, 2000; Roth et al., 2004).

Unlike most other tissues, adipose tissue continuously undergoes expansion and regression throughout adult life. Adipose tissue expansion requires the parallel growth of its capillary network. Therefore, adipogenesis (the formation of adipocytes) is tightly associated with angiogenesis (the formation of new blood vessels). We will review the pro- and anti-angiogenic components that have been demonstrated in adipose tissues, and discuss how modulation of angiogenesis may affect obesity.

\section{Adipose tissue vasculature}

A well-defined vascular system is present in adipose tissue, with every adipocyte surrounded by one or more capillaries. Fat cell development is characterized by the appearance of a number of fat cell clusters, or "primitive organs", which are vascular structures in the adipose tissue with few or no fat cells. During fetal development, arteriolar differentiation precedes adipocyte development and differentiation of blood vessel extracellular matrix (ECM) precedes differentiation of adipocyte ECM (Hausman and Richardson, 2004).

Adipose tissue consists of mature adipocytes surrounded by a stromal-vascular cell fraction containing preadipocytes, endothelial cells, pericytes, fibroblasts, macrophages, and mesenchymal stem cells. Autocrine/paracrine or developmental relationships exist between capillaries/endothelial cells and preadipocytes. In vitro studies revealed that adipose tissue explants in fibrin or collagen gels trigger blood vessel formation (Montesano et al., 1985), and that in turn adipose tissue endothelial cells promote preadipocyte differentiation (Varzaneh et al., 1994). Mature adipocytes in culture can dedifferentiate followed by differentiation into adipocytes or endothelial cells, suggesting that these are derived from a common lineage (Planat-Benard et al., 2004).

The growth of white adipose tissue (WAT) requires continuous remodeling of the vascular network, primarily of primitive capillary networks. Expansion of adipose tissue can be supported by both neovascularization (for adipocyte hyperplasia) and dilation and remodeling of existing capillaries (for adipocyte hypertrophy) (Hausman and Kauffman, 1986). Brown adipose tissue (BAT) is mainly responsible for energy metabolism, and its function requires efficient blood perfusion to supply nutrients and oxygen and to export heat. BAT hyperplasia is critically dependent on angiogenesis, as it requires rapid 
activation of mitosis in fat precursor cells and endothelial cells to develop capillaries (Bukowiecki et al., 1980).

Blood vessel density may not truly reflect angiogenic activity. Microvessel density is often considered a prognostic indicator for cancer. However, microvessel density does not reflect the angiogenic activity or angiogenic dependence of a tumor. The metabolic needs of cancer cells vary with the tissue of origin and change with tumor progression. Thus, the number of tumor cells that can be supported by a vessel varies, influencing in turn the vascular density (Hlatky et al., 2002). In addition, capillary endothelium has important structural features such as microvascular endothelial cells surrounded by capillary fenestrations and transendothelial channels. Several soluble growth factors are found to regulate vascular fenestrations and permeability in adipose tissue. For example leptin increases the vascular permeability in adipose tissue and consequently, influences the microvessel density (Cao et al., 2001). To take this into account, blood vessel density in adipose tissues can be normalized to the adipocyte density.

\section{Regulation of adipose tissue related angiogenesis}

Both WAT and BAT produce and secrete many different types of proangiogenic factors such as vascular endothelial growth factor (VEGF)-A and hepatocyte growth factor (HGF), the two key angiogenic factors produced by adipocytes. Other adipose-tissue derived factors with proangiogenic effects include VEGF-B, VEGF-C, placental growth factor (PlGF), fibroblast growth factor (FGF)-2, SPARC/osteonectin, angiopoietin (Ang)1 , Ang-2, leptin, platelet derived growth factor (PDGF)- $\beta$, transforming growth factor (TGF)- $\beta$, tumor necrosis factor (TNF)- $\alpha$, tissue factor (TF), matrix metalloproteinases (MMPs), plasminogen activators and cathepsins. Adipose tissue also produces endogenous antiangiogenic factors, such as adiponectin, thrombospondin (TSP)-1, TSP2, ADAM and ADAMTS family members. Thus, the regulation of angiogenesis in adipose tissue may depend on the local balance between proangiogenic and antiangiogenic factors. The angiogenic potential of the main pro- or anti-angiogenic components is sometimes context dependent and different in different fat pads.

\subsection{Vascular endothelial growth factors and placental growth factor}

VEGF-A (17-23 kDa) is a major angiogenic factor that stimulates proliferation and migration of endothelial cells. Three forms of VEGF-A are produced in the mouse as a result of alternative splicing (VEGF-A121, VEGF-A165 and VEGF-A189). Several studies indicate that VEGF-A stimulates both physiological and pathological angiogenesis by signaling through vascular endothelial growth factor receptor (VEGFR)2 in a strict dose-dependent manner. Loss of a single VEGF-A allele causes embryonic vascular defects, while reduction of VEGF-A levels by only $25 \%$ impairs spinal cord perfusion, resulting in motor neuron degeneration reminiscent of amyotrophic lateral sclerosis (Carmeliet et al., 1996; Ferrara et al., 1996; Oosthuyse et al., 2001). VEGF-A is believed to be responsible for most of adipose tissue's angiogenic capacity (Zhang et al., 1997). VEGF-B (21 kDa) is $43 \%$ identical to VEGF-A165; it also promotes angiogenesis and is implicated in ECM degradation via regulation of plasminogen activation (Olofsson et al., 1998). VEGF-C (23 kDa) displays 30\% homology with VEGF-A165 and plays an important role both in angiogenesis and lymphangiogenesis (Joukov et al., 1996; Karkkainen et al., 2004). VEGF-D (22 kDa) is $48 \%$ identical to VEGF-C and also 
promotes the growth of lymphatic vessels (Stacker et al., 2001). VEGF is expressed by both stromavascular fraction cells and mature adipocytes, as described in both animals and humans (Ledoux et al., 2008).

PlGF, a $25 \mathrm{kDa}$ homologue of VEGF-A (53\% sequence identity with VEGF-A165), enhances angiogenesis, but only in pathological conditions. Loss of PlGF impairs angiogenesis in the ischemic retina, limb, and heart, in wounded skin and in tumors, without affecting physiological angiogenesis (Carmeliet et al., 2001). PlGF is expressed in murine adipose tissue, both in adipocytes and in the stromal-vascular cell fraction (Voros et al., 2005).

\subsection{VEGF and PIGF receptors}

The members of the VEGF family bind to transmembrane tyrosine kinase receptors (VEGFR-1 (206 kDa), VEGFR-2 (218 kDa) and VEGFR-3 (150 kDa)). VEGF-A interacts with both VEGFR-1 and VEGFR-2, whereas VEGF-B and PIGF bind to VEGFR-1. VEGF-C and VEGF-D activate VEGFR-3, but VEGF-C can also bind to VEGFR-2. VEGFR-1 and VEGFR-2 mediate angiogenesis, whereas VEGFR-3 is involved mainly in lymphangiogenesis (Veikkola et al., 2001). VEGF-A165, PlGF and VEGF-B also bind to another transmembrane receptor, neuropilin-1 (Np-1). Inactivation of the $\mathrm{Np}-1$ gene in mice causes disturbances in development of the vascular and nervous system (Kawasaki et al., 1999).

\subsection{Hepatocyte growth factor, fibroblast growth factor 2 and osteonectin}

HGF is a mesenchyme-derived multifunctional molecule that elicits mitogenic and morphogenic activities in developmental as well as in many pathophysiological processes (Weidmer et al., 1993; Jeffers et al., 1996). Its receptor has been identified as the c-Met tyrosine kinase, a product of the proto-oncogene $c$-met. Both HGF and c-Met play a critical role in the invasive growth of tumor cells, a hallmark of metastatic cancers. HGF secreted by cultured 3T3-L1 adipocytes promotes tube formation of human umbilical vascular endothelial cells (HUVECs) in vitro (Saiki et al., 2006).

FGF-2 $(25 \mathrm{kDa})$ is a potent stimulator of differentiation, migration and proliferation of endothelial cells, and enhances adipocyte differentiation in vivo (Kawaguchi et al., 1998). During angiogenesis, FGF-2 stimulates the synthesis of proteinases such as collagenase and urokinase-type plasminogen activator (uPA), and of integrins to form new capillary cord structures (Okamura et al., 1991; Tienari et al., 1991).

SPARC/osteonectin is a matricellular protein that is thought to modulate cell-matrix interaction. It binds to VEGF-A, impairs VEGFR-1 activation, and inhibits FGF-2, resulting in inhibition of endothelial cell proliferation (Bornstein, 1995). Osteonectin is produced by adipose tissue and its expression is upregulated in obesity (Tartare-Deckert et al., 2001). Osteonectin deficient mice on high fat diet (HFD) develop larger fat pads as compared to wild-type mice (Bradshaw et al., 2003).

\subsection{The angiopoietins, TIE-1 and TIE-2}

Another signaling system contributing to maintenance, growth and stabilization of blood vessels involves the tyrosine kinase (T) with Ig (I) and epidermal (E) growth factor (EGF) homology domains (TIE)-1 and -2 receptors (140-145 $\mathrm{kDa}$ ). TIE-2 binds the angiopoietins (Ang-1 and Ang-2), whereas the ligands of TIE-1 are less well defined. 
Unlike Ang-2, which activates TIE-2 on some cells but blocks it on others (Davis et al., 2003), Ang-1 consistently activates TIE-2 (Davis et al., 1996). The role of Ang-1 in vascularization is pleiotropic and context-dependent. Ang-1 tightens vessels by affecting junctional molecules (Thurston et al., 2000), by promoting the interaction between endothelial cells and mural cells and by recruiting pericytes (Carlson et al., 2001). Ang-2 may stimulate vessel growth by loosening endothelial-peri-endothelial cell interactions and degrading the ECM (Morange et al., 2002). TIE-1 and TIE-2 are expressed by endothelial cells in murine adipose tissues and their expression increases with fat pad development. However, their role in adipose tissue associated angiogenesis has not been clearly established (Neels et al., 2004).

\subsection{Leptin}

Leptin $(16 \mathrm{kDa})$, a satiety hormone produced by mature adipocytes, promotes migration of endothelial cells. Interaction of leptin with its receptor on endothelial cells leads to activation of the Stat3 pathway and enhancement of its DNA binding activity (SierraHonigmann et al., 1998). Besides a direct proangiogenic activity, leptin upregulates VEGF expression via activation of the Jak/Stat3 signaling pathway (Suganami et al., 2004). Similar to VEGF-A, leptin induces the formation of fenestrated capillaries, as confirmed by the absence of fenestrations in leptin deficient $o b / o b$ mice. Leptin has a synergistic effect on stimulation by VEGF and FGF-2 (Cao et al., 2001).

\subsection{Adiponectin}

Adiponectin is an abundant circulating plasma protein secreted by mature adipocytes that mediates beneficial effects in the vasculature. Circulating levels of adiponectin are decreased in individuals with obesity and type 2 diabetes, suggesting a potential role for adiponectin in vascular diseases that frequently accompany these disorders (Matsuzawa, 2006). Pro- as well as anti-angiogenic effects of adiponectin have been reported. Adiponectin inhibited endothelial cell migration and proliferation in vitro and neoangiogenesis in vivo in the chick chorioallantoic membrane (CAM) and cornea assays, and it reduced angiogenesis and induced apoptosis in tumors, obtained by implanting T241 fibrosarcoma cells in mice (Bråkenhielm et al., 2004). Adiponectin suppressed VEGF-induced migration of human coronary artery endothelial cells (HCAECs) via cAMP/PKA-dependent signaling (Mahadev et al., 2008). However, adiponectin has also been reported to activate adenosine monophosphate kinase in endothelial cells, leading to enhanced in vivo angiogenesis in murine Matrigel plug and rabbit cornea assays and to inhibition of caspase 3-mediated apoptosis in HUVECs cultured in vitro (Kobayashi et al., 2004; Ouchi et al., 2004).

\subsection{Growth factors and cytokines}

PDGF was originally purified from platelets; however, it has since been found in many other cell types including fibroblasts, keratinocytes, myoblasts, astrocytes, epithelial cells, and macrophages (Heldin and Westermark, 1999). A recent study shows that macrophage-derived PDGF is involved in the stimulation of angiogenesis during expansion of adipose tissue (Pang et al., 2008).

TGF- $\beta$ is a multifunctional cytokine that is produced by a variety of cells and is capable of regulating the growth and differentiation of many cell types. It is implicated in a 
number of biological processes including cell adhesion and migration, extracellular matrix production, tissue remodeling and wound repair (McCartney-Francis and Wahl, 1994). TGF- $\beta$ mRNA levels are increased in both the mature adipocyte and the stromal/vascular cell fractions of the adipose tissues from obese mice. The augmented expression of TGF- $\beta$ in the obese adipose tissue may increase adipocyte precursor cell proliferation, thereby contributing to the excessive cellularity of the fat depots associated with the obese phenotype (Samad et al., 1997).

TNF- $\alpha$ is a multipotential cytokine with several immunological functions. It was the first product secreted from adipose tissue to be proposed as a molecular link between obesity and insulin resistance. In humans, adipose tissue TNF- $\alpha$ mRNA correlates with body mass index, percentage of body fat and hyperinsulinaemia (Katsuki et al., 1998). TNF- $\alpha$ promotes endothelial cell tube formation in vitro and inhibits endothelial cell proliferation (Papetti et al., 2002). A functional role of TNF- $\alpha$ in adipogenesis and insulin resistance has been studied in the genetically obese and diabetic $o b / o b$ mice (Uysal et al., 1997). TNF- $\alpha$ deficient $o b / o b$ mice showed lower levels of circulating free fatty acids, and were protected from the obesity-related reduction in the insulin receptor signaling in muscle and fat tissues. Interfering with TNF- $\alpha$ signaling through null mutations in TNF receptors p55 and p75 also resulted in a significant protection from the insulin resistance associated with the $o b / o b$ phenotype (Uysal et al., 1997).

\subsection{Tissue factor}

$\mathrm{TF}$ is the major cellular initiator of the coagulation cascade and serves as a cell-surface receptor for the activation of factor VII (Camerer et al., 1996). TF is expressed by both mature adipocytes and stromal/vascular cell fractrions in murine adipose tissue and increased levels of TF in obesity promote the development of a hypercoagulable state and thus may contribute to the cardiovascular complications associated with obesity (Samad et al., 1998). TF is involved in metastasis and indirectly in tumor growth via angiogenesis, as tumor cells transfected to overexpress TF expressed high levels of VEGF and reduced amounts of thrombospondin (Zhang et al., 1994).

\subsection{Proteolytic systems}

Initiation of angiogenesis requires vessel destabilization, which involves weakening of the intercellular contacts between endothelial cells, destruction of the basement membrane, and local proteolysis of matrix proteins to allow the endothelial cells to migrate and produce new capillaries (Lamalice et al., 2007). Proteases of at least three classes (serine, cysteine, and metallo-), including MMPs, members of the urokinase/ plasmin(ogen) system and cysteine cathepsins, play crucial roles in the remodeling of the ECM and therefore in angiogenesis. Proteases participate in the angiogenic process by generating both pro- and anti-angiogenic factors from ECM proteins, and by processing growth factors and receptors (Van Hinsbergh et al., 2006).

The MMPs belong to a family of over 25 neutral endopeptidases that play a role in ECM proteolysis. The vascular localization of MMPs may allow their spatial role in the degradation of subendothelial basement membrane, which is a crucial step in angiogenesis and atherosclerosis. MMPs promote angiogenesis by regulating endothelial cell attachment, proliferation and migration, either directly or by release of growth factors 
sequestered in the ECM (Stetler-Stevenson, 1999). Many MMPs are expressed by mature adipocytes and stromal-vascular cells in a depot-dependent manner (Maquoi et al., 2002). The ADAM (A Disintegrin And Metalloproteinase) family comprises proteins containing disintegrin-like and metalloproteinase-like domains (Wolfsberg et al., 1995). The ADAMTS family includes a subset of ADAM proteins that contain a thrombospondin motif (Kaushal and Shah, 2000). Several ADAM and ADAMTS family members are expressed in adipose tissue and during differentiation of preadipocytes (Voros et al., 2003). ADAMTS-1 and ADAMTS-8 can inhibit VEGF-induced angiogenesis and suppress FGF-2-induced vascularization (Vázquez et al., 1999). They both mediate a greater antiangiogenic response than either TSP-1 or endostatin, with ADAMTS-1 showing a greater inhibitory capacity than ADAMTS-8. The antiangiogenic activity of ADAMTS-1 and -8 is mediated through their TS motifs. Interestingly, ADAMTS-1 deficient mice are exceptionally lean, their volume of epididymal fat is significantly smaller than in wild-type mice and the formation of capillaries in the adrenal gland is drastically impaired (Luque et al., 2003).

The fibrinolytic system comprises an inactive proenzyme, plasminogen, that can be converted to the active enzyme, plasmin, that degrades fibrin into soluble fibrindegradation products. Two immunologically distinct plasminogen activators have been identified: tissue-type plasminogen activator (t-PA) and urokinase-type plasminogen activator (u-PA). u-PA binds to a specific cellular receptor (u-PAR or CD87) resulting in enhanced activation of cell-bound plasminogen. Inhibition of the fibrinolytic system may occur either at the level of plasmin by $\alpha_{2}$-antiplasmin, or at the level of the plasminogen activators, mainly by plasminogen activator-inhibitor-1 (PAI-1) (Lijnen and Collen, 2005). The fibrinolytic system participates in diverse physiologic processes, including blood coagulation, tissue growth and remodeling, wound healing, angiogenesis and embryogenesis. Especially the involvement of uPA and UPAR in angiogenesis is well established. uPA stimulates endothelial cell tube formation on a fibrin matrix, whereas an antibody blocking urokinase binding to uPAR and to soluble UPAR inhibits the effects of uPA. Urokinase and uPA-generated plasmin can activate and release latent MMPs and elastase, as well as growth factors involved in angiogenesis, especially VEGF, bFGF, HGF, TGF $\beta$, and PDGF (Tkachuk et al., 2009).

Several nutritionally induced obesity models in transgenic mice have been used to study the role of the fibrinolytic system in the development of obesity. t-PA-deficient mice, kept on high-fat diet, had higher body weight and adipose tissue mass than wild-type controls (Morange et al., 2002). There was an increase in the number of endothelial cells and stromal cells in the fat tissues, suggesting that targeted inactivation of t-PA increases angiogenesis in adipose tissue. Deficiency in u-PA, in contrast, had no effect on nutritionally induced obesity (Morange et al., 2002). Mice deficient in plasminogen showed reduced fat accumulation associated with reduced differentiation of stromal cells (Hoover-Plow et al., 2002). Deficiency of $\alpha 2$-antiplasmin had no significant effect on adipose tissue development in mice (Lijnen, 2007). Some studies with transgenic mice reported that PAI-1 deficiency has little or no effect on adipose tissue development (Morange et al., 2000; Lijnen, 2005), whereas others found impaired development (Ma et al., 2004). Disruption of the PAI-1 gene in $o b / o b$ mice resulted in reduced adiposity and improvement of the metabolic profile (Schäfer et al., 2001). 
Cathepsin B, a lysosomal cysteine protease, regulates both pro- and anti-angiogenic factors suggesting that it may be a contributor to the "angiogenic switch" of endothelial cells (Im et al., 2005). Lack of cathepsin B reduces angiogenesis in a mouse model of pancreatic islet cell carcinogenesis (RIP1-Tag2) crossed with cathepsin B-null mice (Gocheva et al., 2006). Cathepsin B has also been shown to exert antiangiogenic effects through its ability to cleave collagen XVIII to generate endostatin, an antiangiogenic factor present in caveolae of endothelial cells. Active cathepsin B is also associated with caveolae and degradation and remodeling of the ECM during endothelial cell migration and tube formation (Cavallo-Medved et al., 2009). Cathepsin B is found to be secreted by human adipose tissue (Alvarez-Llamas et al., 2007).

Overall, the balance of protease activity and the interaction of proteases with the ECM contribute to regulation of the angiogenic process.

\subsection{Thrombospondins}

TSP-1 and TSP-2 are components of the ECM in remodeling tissues and, like other matricellular proteins, bind to matrix proteins and cell-surface receptors, including proteoglycans, non-integrin and integrin receptors. TSPs can inhibit angiogenesis in several different ways (migration, proliferation, tube formation, apoptosis of endothelial cells) in vitro (Armstrong and Bornstein, 2003). Despite its pleiotropic biological role, mice deficient in TSP-1 are viable and exhibit only subtle abnormalities in development, although they develop pneumonia and show delayed organization and neovascularization of skin wounds (Agah et al., 2002). In contrast, TSP-2 deficient mice display a pleiotropic phenotype that includes fragile skin, which is associated with abnormal collagen fibrillogenesis, increased vascularity primarily in reponse to injury, increased cortical bone density, and a bleeding diathesis (Kyriakides et al., 1998). Both TSP-1 and TSP-2 are found to be secreted by human adipose tissue (Alvarez-Llamas et al., 2007).

\section{Modulation of angiogenesis in adipose tissue}

Modulation of development of the vascular network in adipose tissue may constitute a strategy to affect obesity. Therefore, it is important to obtain information on expression and functional role of pro- and anti-angiogenic components in in vitro models of adipogenesis and in in vivo models of obesity.

\subsection{Expression of angiogenic factors during adipose tissue development}

During differentiation of 3T3-F442A preadipocytes into mature adipocytes mRNAs for Ang-1, the VEGF-A isoforms and PlGF are upregulated; FGF-2 and Np-1 expression is transiently upregulated, whereas the expression of Ang-2 is high in confluent cultures but decreases during maturation. TSP-1 and TSP-2 expression are downregulated in the early phase of differentiation but increase again in later phases. VEGF-B, VEGF-C and VEGFR-1 mRNA levels are less modulated during differentiation. TIE-1, TIE-2, VEGFR-2 and VEGFR-3 are not expressed at detectable levels (Voros et al., 2005).

Development of vasculature and mRNA expression of pro- or anti-angiogenic factors were also studied during adipose tissue development in nutritionally induced (HFD) or genetically determined ( $o b / o b)$ murine obesity models (Voros et al., 2005). Ob/ob mice and $\mathrm{C} 57 \mathrm{Bl} / 6$ mice on HFD had significantly larger subcutaneous (SC) and gonadal (GON) fat pads, accompanied by significantly higher blood content, increased total blood 
vessel volume and higher number of proliferating endothelial cells, as compared to lean controls. Ang-1 expression was downregulated, whereas TSP-1 was upregulated in developing adipose tissue in both obesity models. Despite this upregulation, TSP-1 deficiency in mice did not significantly affect adipose tissue development (Voros and Lijnen, 2006); its role in adipose tissue associated angiogenesis thus remains unclear. Ang-1 mRNA levels correlated negatively, and TSP-1 mRNA levels correlated positively with adipose tissue weight. PlGF and Ang-2 expression were increased in SC adipose tissue of $o b / o b$ mice and TSP-2 was increased in both their SC and GON fat pads. mRNA levels of VEGF-A isoforms, VEGF-B, VEGF-C, VEGFR-1, -2 and -3 and Np-1 were not markedly modulated by obesity (Voros et al., 2005).

Several angiogenic factors, like VEGF-C, VEGF-D, sVEGFr2 angiopoietin-2, angiogenin and the angiogenesis inhibitor endostatin are significantly elevated in either overweight or obese subjects compared to lean controls. Although it remains to be proven, it is likely that adipose tissue itself contributes to the elevated circulating levels of these factors. Therefore, adipose tissue may contribute to increased risk of metastatic disease in obese subjects with cancer (Silha et al., 2005).

\subsection{Animal models of genetic modification of angiogenic factors}

Nutritionally induced obesity models in transgenic mice were used to study the role of some angiogenic factors in adipose tissue development.

To establish a functional role in obesity, PlGF deficient $\left(\mathrm{PlGF}^{-/}\right)$and wild type mice with the same genetic background were kept on HFD for 15 weeks. PlGF ${ }^{-/}$mice had a significantly lower body weight and less total SC plus GON adipose tissue. Blood vessel size was lower in GON adipose tissue of $\mathrm{PlGF}^{-/-}$mice, and blood vessel density, normalized to adipocyte number, was significantly lower in SC adipose tissue of $\mathrm{PlGF}^{-/}$ mice. These differences were not observed for $\mathrm{PlGF}^{-/-}$and wild type mice kept on normal chow. These observations are in line with the emerging concept that PlGF deficiency has little or no effect on angiogenesis under normal (feeding) conditions, but is associated with impaired angiogenesis under stress conditions (HFD) during the early stages of adipose tissue formation (Lijnen et al., 2006).

The contribution of HGF to adipose tissue angiogenesis was examined using the 3T3F442A in vivo fat pad formation model (Green and Kehinde, 1979). Silencing of HGF in 3T3-F442A preadipocytes, before injection under the skin of nude mice, impaired the ability of the developing fat pads to recruit endothelial cells for neovascularization. On the other hand, excess HGF accelerated endothelial cell migration in the fat pad (Bell et al., 2008).

Several findings suggest that lymphangiogenesis may also play an important role in development of adipose tissue. The observation that mice lacking Prox1, a gene required for the formation of lymphatic endothelial cells, display adult-onset obesity indicates a link between lymph fluid and fat deposition (Harvey et al., 2005). Adipogenesis and fat deposition are known to occur efficiently around lymph nodes, where the adipocytes provide energy for local lymphoid metabolic needs (Schneider et al., 2005). VEGF-D is mitogenic for endothelial cells and has angiogenic as well as lymphangiogenic potential in vivo (Saharinen et al., 2004). However, a nutritionally induced obesity model in VEGF-D deficient mice did not reveal an important role of VEGF-D in (lymph) angiogenesis or in adipose tissue development (Lijnen et al., 2009). These results do, 
however, not allow to conclude that lymphangiogenesis would not play a role in adipose tissue development.

\section{Pharmacologic inhibition of angiogenesis impairs adipose tissue development}

3T3-F442A preadipocytes injected into severe combined immunodeficient (SCID) mice induce angiogenesis and differentiate into adipocytes (Mandrup et al., 1997). It was reported that neovasculature in the new adipose tissue originates by sprouting from larger hostderived blood vessels that run parallel to peripheral nerves and that endothelial progenitor cells do not play an important role in this process (Neels et al., 2004). Adipogenesis and de novo fat pad formation in this model can be impaired by inhibition of PPAR- $\gamma$ or VEGFR-2 (Fukumura et al., 2003) and by administration of a PlGF neutralizing monoclonal antibody (Lijnen et al., 2006). Furthermore, adipose tissue growth in mice can be impaired with angiogenesis inhibitors such as TNP-470 (a synthetic analog of fumagillin, that selectively inhibits endothelial cell growth by suppression of methionine aminopeptidase), angiostatin (a plasminogen fragment containing kringles 1-4) and endostatin (a COOH-terminal fragment of collagen XVIII) (Rupnick et al., 2002). These agents are also able to cause weight reduction in aged, relatively weight-stable $o b / o b$ mice, suggesting that adipose tissue blood vessels are relatively immature and susceptible to inhibitors even when no longer growing. Another study, using life adipose tissue imaging techniques, demonstrated that angiogenesis in obesity requires a close interplay between differentiating adipocytes, stromal cells and blood cells (Nishimura et al., 2007). The use of an anti-VEGF antibody indeed inhibited not only angiogenesis, but also the formation of adipo/angiogenic cell clusters, indicating that coupling of adipogenesis and angiogenesis is essential for differentiation of adipocytes in obesity, and confirming that VEGF is a key mediator (Nishimura et al., 2007). The implication of VEGF in adipose tissue angiogenesis was also evidenced for human tissue, using anti-VEGF antibodies (Ledoux et al., 2008). A recent study showed that blockade of VEGFR-2 but not VEGFR-1, using monoclonal antibodies, can limit diet-induced fat tissue expansion in mice. The results also indicated that angiogenesis from local preexisting vasculature, and not the contribution of bone marrow-derived cells, primarily sustains new vessel formation in fat tissue during diet-induced obesity (Tam et al., 2009).

Another strategy to reduce fat mass via its vasculature may be to target prohibitin, a multifunctional membrane protein selectively expressed in adipose tissue endothelial cells (Kolonin et al., 2004). Ablation of fat tissue can be achieved with a synthetic peptide, that binds to prohibitin and induces apoptosis in adipose tissue blood vessels. Dietary curcumin, the major polyphenol in turmeric spice, may also have a potential benefit in preventing obesity. Supplementing the high-fat diet of mice with curcumin reduced body weight gain, adiposity, and microvessel density in adipose tissue, which coincided with reduced expression of VEGF and VEGFR-2. Curcumin also had a beneficial effect on lipid metabolism (Ejaz et al., 2009).

\section{Adipose tissue as a source for therapeutic angiogenesis}

Therapeutic angiogenesis using autologous stem/progenitor cells represents a novel strategy for severe ischemic diseases. A number of recent studies, both in animals and humans, demonstrated that implantation of autologous bone marrow mononuclear cells 
into ischemic skeletal muscles successfully augmented angiogenesis and collateral vessel formation (Murohara, 2009). Since bone marrow aspiration is relatively invasive for patients with severe ischemic diseases, less invasive techniques for isolating cells for angiogenic therapy are warranted. Autologous subcutaneous adipose tissue has been proposed as an interesting cell source for therapeutic angiogenesis, since it can be harvested by minimal invasive technology. The stromal vascular fraction of adipose tissue contains multipotent mesenchymal stem/progenitor cells, called adipose-derived stem/progenitor cells (ASCs). These cells can differentiate into various lineages including fibroblasts, adipocytes, pericytes, osteoblasts, chondrocytes, and myocytes, and have the ability to regenerate damaged tissues (Zuk et al., 2001). ASCs can also release multiple angiogenesis-related growth factors including VEGF, HGF, and chemokine stromal cellderived factor-1 (SDF-1). The combination of these biological properties (i.e. progenitor cell supply and growth factor release) suggests that autologous subcutaneous adipose tissue may be a next generation candidate as cell source for therapeutic angiogenesis. Murine, as well as human adipose tissue-derived stromal cells, augmented new vessel formation when transplanted into the ischemic hind limb in mice, confirming the potential therapeutic value (Rehman et al., 2004; Sumi et al., 2007).

\section{Future lines of investigation}

Modulation of angiogenesis appears to have the potential to impair development of obesity. In particular, the VEGF/VEGFR signaling system may be an attractive target. Recent studies have suggested that the expression pattern of pro- and anti-angiogenic components in adipose tissue is fat depot dependent. A better understanding of the regulation of their expression will thus be instrumental in the development of specific targeting approaches. Little is known either on the interactions between these angiogenic components in adipose tissues and on the interplay with adipokines, such as leptin, resistin and adiponectin. The interactions between adipocytes and endothelial cells also remain to be elucidated in more detail. The contribution of inflammatory cell derived cytokines, such as TNF- $\alpha$ and several interleukins (e.g. IL-6 and IL-8), to adipogenesis and angiogenesis in adipose tissues also needs further study. Since more and more antiangiogenic agents are characterized in the cancer field, there is a real option to evaluate such components in obesity models in vivo. However, since development of adipose tissue is a complex and multifactorial process, it is unlikely that a single angiogenesis inhibitor will allow reduction of obesity without associated side effects. It should indeed be kept in mind that the angiogenic components involved in adipogenesis and adipose tissue development also are critical to many other biological processes. 


\section{References}

Agah, A., Kyriakides, T.R., Lawler, J., Bornstein, P., 2002. The lack of thrombospondin1 (TSP1) dictates the course of wound healing in double-TSP1/TSP2-null mice. Am. J. Pathol. 161, 831-839.

Alvarez-Llamas, G., Szalowska, E., de Vries, M.P., Weening, D., Landman, K., Hoek, A., Wolffenbuttel, B.H.R., Roelofsen, H., Vonk, R.J., 2007. Characterization of the human visceral adipose tissue secretome. Mol. Cell. Proteomics 6, 589-600.

Armstrong, L.C., Bornstein, P., 2003. Thrombospondins 1 and 2 function as inhibitors of angiogenesis. Matrix Biol. 22, 63-71.

Bell, L.N., Cai, L., Johnstone, B.H., Traktuev, D.O., March, K.L., Considine, R.V., 2008. A central role for hepatocyte growth factor in adipose tissue angiogenesis. Am. J. Physiol. Endocrinol. Metab. 294, E336-E344.

Bradshaw, A.D., Graves, D.C., Motamed, K., Sage, E.H., 2003. SPARC-null mice exhibit increased adipocity without significant differences in overall body weight. Proc. Natl. Acad. Sci. USA 100, 6045-6050.

Bråkenhielm, E., Veitonmåki, N., Cao, R., Kihara, S., Matsuzawa, Y., Zhivotovsky, B., Funahashi, T., Cao, Y., 2004. Adiponectin-induced antiangiogenesis and antitumor activity involve caspase-mediated endothelial cell apoptosis. Proc. Natl. Acad. Sci. USA 101, 2476-2481.

Bornstein, P., 1995. Diversity of function is inherent in matricellular proteins: an appraisal of thrombospondin-1. J. Cell. Biol. 130, 503-506.

Bukowiecki, L., Lupien, J., Follea, N., Paradis, A., Richard, D., LeBlanc, J., 1980. Mechanism of enhanced lipolysis in adipose tissue of exercise-trained rats. Am. J. Physiol. 239, E422-E429.

Camerer, E., Kolsto, A.B., Prydz, H., 1996. Cell biology of tissue factor, the principal initiator of blood coagulation. Thromb. Res. 81, 1-41.

Cao, R., Bråkenhielm, E., Wahlestedt, C., Thyberg, J., Cao, Y., 2001. Leptin induces vascular permeability and synergistically stimulates angiogenesis with FGF-2 and VEGF. Proc. Natl. Acad. Sci. USA 98, 6390-6395.

Carlson, T.R., Feng, Y., Maisonpierre, P.C., Mrksich, M., Morla, A.O., 2001. Direct cell adhesion to the angiopoietins mediated by integrins. J. Biol. Chem. 276, 26516-26525.

Carmeliet, P., Ferreira, V., Breier, G., Pollefeyt, S., Kieckens, L., Gertsenstein, M., Fahriq, M., Vandenhoeck, A., Harpal, K., Eberhardt, C., Declercq, C., Pawling, J., Moons, L., Collen, D., Risau, W., Nagy, A., 1996. Abnormal blood vessel development and lethality in embryos lacking a single VEGF allele. Nature 380, 435-439.

Carmeliet, P., Moons, L., Luttun, A., Vincenti, V., Compernolle, V., De Mol, M., Wu, Y., Bono, F., Devy, L., Beck, H., Scholz, D., Acker, T., DiPalma, T., Dewerchin, M., Noel, A., Stalmans, I., Barra, A., Blacher, S., Vandendriessche, T., Ponten, A., Eriksson, U., Plate, K.H., Foidart, J.M., Schaper, W., Charnock-Jones, D.S., Hicklin, D.J., Herbert, J.M., Collen, D., Persico, M.G., 2001. Synergism between vascular endothelial growth factor and placental growth factor contributes to angiogenesis and plasma extravasation in pathological conditions. Nat. Med. 7, 575-583.

Cavallo-Medved, D., Rudy, D., Blum, G., Bogyo, M., Caglic, D., Sloane, B.F., 2009. Live-cell imaging demonstrates extracellular matrix degradation in association with active cathepsin $\mathrm{B}$ in caveolae of endothelial cells during tube formation. Exp. Cell. Res. 315, 1234-1246. 
Davis, S., Aldrich, T.H., Jones, P.F., Acheson, A., Compton, D.L., Jain, V., Ryan, T.E., Bruno, J., Radziejewski, C., Maisonpierre, P.C., Yancopoulos, G.D., 1996. Isolation of angiopoietin-1, a ligand for the TIE-2 receptor, by secretion-trap expression cloning. Cell 87, 1161-1169.

Davis, S., Papadopoulos, N., Aldrich, T.H., Maisonpierre, P.C., Huang, T., Kovac, L., Xu, A., Leidich, R., Radziejewska, E., Rafique, A., Goldberg, J., Jain, V., Bailey, K., Karow, M., Fandl, J., Samuelsson, S.J., Ioffe, E., Rudge, J.S., Daly, T.J., Radziejewski, C., Yancopoulos, G.D., 2003. Angiopoietins have distinct modular domains essential for receptor binding, dimerization and superclustering. Nat. Struct. Biol. 10, 38-44.

Ejaz, A., Wu, D., Kwan, P., Meydani, M., 2009. Curcumin inhibits adipogenesis in 3T3L1 adipocytes and angiogenesis and obesity in C57/BL mice. J. Nutr. 139, 919-925.

Ferrara, N., Carver-Moore, K., Chen, H., Dowd, M., Lu, L., O'Shea, K.S., PowellBraxton, L., Hilan, K.J., Moore, M.W., 1996. Heterozygous embryonic lethality induced by targeted inactivation of the VEGF gene. Nature 380, 439-442.

Fukumura, D., Ushiyama, A., Duda, D.G., Xu, L., Tam, J., Krishna, V., Chatterjee, K., Garkavtsev, I., Jain, R.K., 2003. Paracrine regulation of angiogenesis and adipocyte differentiation during in vivo adipogenesis. Circ. Res. 93, e88-e97.

Gocheva, V., Zeng, W., Ke, D., Klimstra, D., Reinheckel, T., Peters, C., Hanahan, D., Joyce, J.A., 2006. Distinct roles for cysteine cathepsin genes in multistage tumorigenesis. Genes Dev. 20, 543-556.

Green, H., Kehinde, O., 1979. Formation of normally differentiated subcutaneous fat pads by an established preadipose cell line. J. Cell. Physiol. 101, 169-171. Harvey, N.L., Srinivasan, R.S., Dillard, M.E., Johnson, N.C., Witte, M.H., Body, K., Sleeman, M.W., Oliver, G., 2005. Lymphatic vascular defects promoted by Prox1 haploinsufficiency cause adult-onset obesity. Nat. Genet. 37, 1072-1081.

Hausman, G.J., Kauffman R.G., 1986. The histology of developing porcine adipose tissue. J. Anim. Sci. 63, 642-658.

Hausman, G.J., Richardson, R.L., 2004. Adipose tissue angiogenesis. J. Anim. Sci. 82, 925-934.

Hedley, A.A., Ogden, C.L., Johnson, C.L., Carroll, M.D., Curtin, L.R., Flegal, K.M., 2004. Prevalence of overweight and obesity among US children, adolescents, and adults 1999-2000. JAMA 291, 2847-2850.

Heldin, C.H., Westermark, B., 1999. Mechanism of action and in vivo role of plateletderived growth factor. Physiol. Rev. 79, 1283-1316.

Hlatky, L., Hahnfeldt, P., Folkman, J., 2002. Clinical application of antiangiogenic therapy: microvessel density, what it does and doesn't tell us. J. Natl. Cancer Inst. 94, 883-893.

Hoover-Plow, J., Ellis, J., Yuen, L., 2002. In vivo plasminogen deficiency reduces fat accumulation. Thromb. Haemost 87, 1011-1019.

Im, E., Venkatakrishnan, A., Kazlauskas, A., 2005. Cathepsin B regulates the intrinsic angiogenic threshold of endothelial cells. Mol. Biol. Cell 16, 3488-3450.

Jeffers, M., Rong, S., Woude, G.F., 1996. Hepatocyte growth factor/scatter factor-Met signaling in tumorigenicity and invasion/metastasis. J. Mol. Med. 74, 505-513.

Joukov, V., Pajusola, K., Kaipainen, A., Chilov, D., Lahtinen, I., Kukk, E., Saksela, O., Kalkkinen, N., Alitalo, K., 1996. A novel vascular endothelial growth factor, VEGF-C, is 
a ligand for the Flt4 (VEGFR-3) and KDR (VEGFR-2) receptor tyrosine kinases. EMBO J. 15, 290-298.

Karkkainen, M.J., Haiko, P., Sainio, K., Partanen, J., Taipale, J., Petrova, T.V., Jeltsch, M., Jackson, D.G., Talikka, M., Rauvala, H., Betsholtz, C., Alitalo, K., 2004. Vascular endothelial growth factor $\mathrm{C}$ is required for sprouting of the first lymphatic vessels from embryonic veins. Nat. Immunol. 5, 74-80.

Katsuki, A., Sumida, Y., Murashima, S., Murata, K., Takarada, Y., Ito, K., Fujii, M., Tsuchihashi, K., Goto, H., Nakatani, K., Yano, Y., 1998. Serum levels of tumor necrosis factor-alpha are increased in obese patients with noninsulin-dependent diabetes mellitus. J. Clin. Endocrinol. Metab. 83, 859-862.

Kaushal, G.P., Shah, S.B., 2000. The new kids on the block: ADAMTSs, potentially multifunctional metalloproteinases of the ADAM family. J. Clin. Invest. 105, 1335-1337.

Kawaguchi, N., Toriyama, K., Nicodemou-Lena, E., Inou, K., Torii, S., Kitagawa, Y., 1998. De novo adipogenesis in mice at the site of injection of basement membrane and basic fibroblast growth factor. Proc. Natl. Acad. Sci. USA 95, 1062-1066.

Kawasaki, T., Kitsukawa, T., Bekku, Y., Matsuda, Y., Sanbo, M., Yagi, T., Fujisawa, H., 1999. A requirement for neuropilin-1 in embryonic vessel formation. Dev. 126, 48954902.

Kobayashi, H., Ouchi, N., Kihara, S., Walsh, K., Kumada, M., Abe, Y., Funahashi, T., Matsuzawa, Y., 2004. Selective suppression of endothelial cell apoptosis by the high molecular weight form of adiponectin. Circ. Res. 94, 27-31.

Kolonin, M.G., Saha, P.K., Chan, L., Pasqualini, R., Arap, W., 2004. Reversal of obesity by targeted ablation of adipose tissue. Nat. Med. 10, 625-632.

Kopelman, P.G., 2000. Obesity as a medical problem. Nature 404, 635-643.

Lamalice, L., Le Boeuf, F., Huot, J., 2007. Endothelial cell migration during angiogenesis. Circ. Res. 100, 782-794.

Kyriakides, T.R., Zhu, Y.H., Smith, L.T., Bain, S.D., Yang, Z., Lin, M.T., Danielson, K.G., Iozzo, R.V., LaMarca, M., McKinney, C.E., Ginns, E.I., Bornstein, P., 1998. Mice that lack thrombospondin 2 display connective tissue abnormalities that are associated with disordered collagen fibrillogenesis, an increased vascular density, an a bleeding diathesis. J. Cell Biol. 140, 419-430.

Ledoux, S., Queguiner, I., Msika, S., Calderari, S., Rufat, P., Gasc, J., Corvol, P., Larger, E., 2008. Angiogenesis associated with visceral and subcutaneous adipose tissue in severe human obesity. Diabetes 57, 3247-3257.

Lijnen, H.R., 2005. Effect of plasminogen activator inhibitor-1 deficiency on nutritionally-induced obesity in mice. Thromb. Haemost. 93, 816-819.

Lijnen, H.R., Collen, D., 2005. Molecular and cellular basis of fibrinolysis. In: Hoffman, R., Benz, E.J., Shattil, S.J., Furie, B., Cohen, H.J., Silberstein, L.E., McGlave, P., editors. Hematology: basic principles and practive. $4^{\text {th }}$ ed., Philadelphia: Elsevier, 1955-1959.

Lijnen, H.R., Christiaens, V., Scroyen, I., Voros, G., Twja, M., Carmeliet, P., Collen, D., 2006. Impaired adipose tissue development in mice with inactivation of placental growth factor function. Diabetes 55, 2698-2704.

Lijnen, H.R., 2007. Deficiency of $\alpha 2$-antiplasmin does not affect murine adipose tissue development. J. Thromb. Haemost. 5, 420-421. 
Lijnen, H.R., Frederix, L., Van Hoef, B., Dewerchin, M., 2009. Deficiency of vascular endothelial growth factor-D does not affect murine adipose tissue development. Biochem. Biophys. Res. Commun. 378, 255-258.

Luque, A., Carpizo, D.R., Iruela-Arispe, M.L., 2003. ADAMTS1/METH1 inhibits endothelial cell proliferation by direct binding and sequestration of VEGF 165. J. Biol. Chem. 278, 23656-23665.

Ma, L.F., Mao, S.L., Taylor, K.L., Kanjanabuch, T., Guan, Y., Zhang, Y., Bown, N.G., Swift, L.L., McGuinness, O.P., Wasserman, D.H., Vaughan, D.E., Fogo, A.B., 2004. Prevention of obesity and insulin resistance in mice lacking plasminogen activator inhibitor-1. Diabetes 53, 336-346.

Mahadev, K., Wu, X., Donnelly, S., Ouedraogo, R., Eckhart, A.D., Goldstein, B.J., 2008. Adiponectin inhibits vascular endothelial growth factor-induced migration of human coronary artery endothelial cells. Cardiovasc. Res. 78, 376-384.

Mandrup, S., Loftus, T.M., MacDougald, O.A., Kuhajda, F.P., Lane, M.D., 1997. Obese gene expression at in vivo levels by fat pads derived from s.c. implanted 3T3-F442A preadipocytes. Proc. Natl. Acad. Sci. USA 94, 4300-4305.

Matsuzawa, Y., 2006. Therapy insight: adipocytokines in metabolic syndrome and related cardiovascular disease. Nat. Clin. Pract. Cardiovasc. Med. 3, 35-42.

Maquoi, E., Munaut, C., Colige, A., Collen, D., Lijnen, H.R., 2002. Modulation of adipose tissue expression of murine matrix metalloproteinases and their tissue inhibitors with obesity. Diabetes 51, 1093-1101.

McCartney-Francis, N.L., Wahl, S.M., 1994. Transforming growth factor beta: A matter of life and death. J. Leukocyte Biol. 55, 401-409.

Montesano, R., Mouron, P., Orci, L., 1985. Vascular outgrowths from tissue explants embedded in fibrin or collagen gels: a simple in vitro model of angiogenesis. Cell. Biol. Int. Rep. 9, 869-875.

Morange, P.E., Lijnen, H.R., Alessi, M.C., Kopp, F., Collen, D., Juhan-Vague, I., 2000. Influence of PAI-1 on adipose tissue growth and metabolic parameters in a murine model of diet-induced obesity. Arterioscler. Thromb. Vasc. Biol. 20, 1150-1154.

Morange, P.E., Bastelica, D., Bonzi, M.F., Van Hoef, B., Collen, D., Juhan-Vague, I., Lijnen, H.R., 2002. Influence of t-PA and u-PA on adipose tissue development in a murine model of diet-induced obesity. Thromb. Haemost. 87, 306-310.

Murohara, T., 2009. Autologous adipose tissue as a new source of progenitor cells for therapeutic angiogenesis. J. Cardiol. 53, 155-163.

Neels, J.G., Thinnes, T., Loskutoff, D.J., 2004. Angiogenesis in an in vivo model of adipose tissue development. Faseb J. 18, 983-985.

Nishimura, S., Manabe, I., Nagasaki, M., Hosoya, Y., Yamashita, H., Fujita, H., Ohsugi, M., Tobe, K., Kadowaki, T., Nagai, R., Sugiura, S., 2007. Adipogenesis in obesity requires close interplay between differentiating adipocytes, stromal cells and blood vessels. Diabetes 56, 1517-1526.

Okamura, K., Sato, Y., Matsuda, T., Hamanaka, R., Ono, M., Kohno, K., Kuwano, M., 1991. Endogenous basic fibroblast growth factor-dependent induction of collagenase and interleukin-6 in tumor necrosis factor-treated human microvascular endothelial cells. J. Biol. Chem. 266, 19162-19165.

Olofsson, B., Korpelainen, E., Pepper, M.S., Mandriota, S.J., Aase, K., Kumar, V., Gunji, Y., Jeltsch, M.M., Shibuya, M., Alitalo, K., Eriksson, U., 1998. Vascular endothelial 
growth factor B (VEGF-B) binds to VEGF receptor-1 and regulates plasminogen activator activity in endothelial cells. Proc. Natl. Acad. Sci. USA 95, 11709-11714. Oosthuyse, B., Moons, L., Storkebaum, E., Beck, H., Nuyens, D., Brusselmans, K., Van Dorpe, J., Hellings, P., Gorselink, M., Heymans, S., Theilmeier, G., Dewerchin, M., Laudenbach, V., Vermylen, P., Raat, H., Acker, T., Vleminckx, V., Van Den Bosch, L., Cashman, N., Fujisawa, H., Drost, M.R., Sciot, R., Bruyninckx, F., Hicklin, D.J., Ince, C., Gressens, P., Lupu, F., Plate, K.H., Robberecht, W., Herbert, J.M., Collen, D., Carmeliet, P., 2001. Deletion of the hypoxia-response element in the vascular endothelial growth factor promoter causes motor neuron degeneration. Nat. Genet. 28, 131-138.

Ouchi, N., Kabayashi, H., Kihara, S., Kumada, M., Sato, K., Inoue, T., Funahashi, T., Walsh, K., 2004. Adiponectin stimulates angiogenesis by promoting cross-talk between AMP-activated protein kinase and Akt signaling in endothelial cells. J. Biol. Chem. 279, 1304-1309.

Pang, C., Gao, Z., Yin, J., Zhang, J., Jia, W., Ye, J., 2008. Macrophage infiltration into adipose tissue may promote angiogenesis for adipose tissue remodeling in obesity. Am. J. Physiol. Endocrinol. Metab. 295, E313-E322.

Papetti, M., Herman, I.M., 2002. Mechanisms of normal and tumor-derived angiogenesis. Am. J. Physiol. Cell. Physiol. 282, C947-C970.

Planat-Benard, V., Silvestre, J.S., Cousin, B., Andre, M., Nibbelink, M., Tamarat, R., Clergue, M., Manneville, C., Saillan-Barreau, C., Duriez, M., Tedgui, A., Levy, B., Pénicaud, L., Casteilla, L., 2004. Plasticity of human adipose lineage cells toward endothelial cells: physiological and therapeutic perspectives. Circulation 109, 656-663.

Rehman, J., Traktuev, D., Li, J., Merfeld-Clauss, S., Temm-Grove, C.J., Bovenkerk, J.E., Pell, C.L., Johnstone, B.H., Considine, R.V., March, K.L., 2004. Secretion of angiogenic and antiapoptotic factors by human adipose stromal cells. Circulation 109, 1292-1298.

Roth, J., Qiang, X., Marban, S.L., Redelt, H., Lowell, B.C., 2004. The obesity pandemic; where have we been and where are we going? Obes. Res. 12 Suppl. 2, 88S-101S.

Rupnick, M.A., Panigrahy, D., Zhang, C.Y., Dallabrida, S.M., Lowell, B.B., Langer, R., Folkman, M.J., 2002. Adipose tissue mass can be regulated through the vasculature. Proc. Natl. Acad. Sci. USA 99, 10730-10735.

Saharinen, P., Tammelaa, T., Karkkainen, M.J., Alitalo, K., 2004. Lymphatic vasculature: development, molecular regulation and role in tumor metastasis and inflammation. Trends Immunol. 25, 387-395.

Saiki, A., Watanabe, F., Murano, T., Miyashita, Y., Shirai, K., 2006. Hepatocyte growth factor secreted by cultured adipocytes promotes tube formation of vascular endothelial cells in vitro. Int. J. Obes. 30, 1676-1684.

Samad, F., Yamamoto, K., Pandey, M., Loskutoff, D.J., 1997. Elevated expression of transforming growth factor- $\beta$ in adipose tissue from obese mice. Mol. Med. 3, 37-48.

Samad, F., Pandey, M., Loskutoff, D.J., 1998. Tissue factor gene expression in the adipose tissues of obese mice. Proc. Natl. Acad. Sci. USA 95, 7591-7596.

Schneider, M., Conway, E.M., Carmeliet, P., 2005. Lymph makes you fat. Nat. Genet. 37, 1023-1024.

Schäfer, K., Fujisawa, K., Konstantinides, S., Loskutoff, D.J., 2001. Disruption of the plasminogen activator inhibitor-1 gene reduces the adiposity and improves the metabolic profile of genetically obese and diabetic $o b / o b$ mice. FASEB J. 15, 1840-1842. 
Sierra-Honigmann, M.R., Nath, A.K., Murakami, C., Garcia-Cardena, G., Papapetropoulos, A., Sessa, W.C., Madge, L.A., Schechner, J.S., Schwabb, M.B., Polverini, P.J., Flores-Riveros, J.R., 1998. Biological action of leptin as an angiogenic factor. Science 281, 1683-1686.

Silha, J.V., Krsek, M., Sucharda, P., Murphy, L.J., 2005. Angiogenic factors are elevated in overweight and obese individuals. Int. J. Obesit 29, 1308-1314.

Stacker, S.A., Caesar, C., Baldwin, M.E., Thornton, G.E., Williams, R.A., Prevo, R., Jackson, D.G., Nishikawa, S., Kubo, H., Achen, M.G., 2001. VEGF-D promotes the metastatic spread of tumor cells via the lymphatics. Nat. Med. 7, 186-189.

Stetler-Stevenson, W.G., 1999. Matrix metalloproteinase in angiogenesis: a moving target for therapeutic intervention. J. Clin. Invest. 103, 1237-1241.

Suganami, E., Takagi, H., Ohashi, H., Suzuma, K., Suzuma, I., Oh, H., Watanabe, D., Ojima, T., Suganami, T., Fujio, Y., Nakao, K., Ogawa, Y., Yoshimura, N., 2004. Leptin stimulates ischemia-induced retinal neovascularization: possible role of vascular endothelial growth factor expressed in retinal endothelial cells. Diabetes 53, 2443-2448.

Sumi, M., Sata, M., Taya, N., Yanaga, K., Ohki, T., Nagal, R., 2007. Transplantation of adipose stromal cells, but not mature adipocytes, augments ischemia-induced angiogenesis. Life Sci. 80, 559-565.

Tam, J., Duda, D.G., Perentes, J.Y., Quadri, R.S., Fukumura, D., Jain, R.K., 2009. Blockade of VEGFR2 and not VEGFR1 can limit diet-induced fat tissue expansion: role of local versus bone marrow-derived endothelial cells. PloS ONE 4, e4974.

Tartere-Deckert, S., Chavey, C., Monthouel, M.N., Gautier, N., Van Obberghen, E., 2001. The matricellular protein SPARC/osteonectin as a newly identified factor upregulated in obesity. J. Biol. Chem. 276, 22231-22237.

Thurston, G., Rudge, J.S., Ioffe, E., Zhou, H., Ross, L., Croll, S.D., Glazer, N., Holash, J., McDonald, D.M., Yancopoulos, G.D., 2000. Angiopoietin-1 protects the adult vasculature against plasma leakage. Nat. Med. 6, 460-463.

Tienari, J., Alanko, T., Lehtonen, E., Saksela, O., 1991. The expression and localization of urokinase-type plasminogen activator and its type 1 inhibitor are regulated by retinoic acid and fibroblast growth factor in human teratocarcinoma cells. Cell. Regul. 2, 285297.

Tkachuk, V.A., Plekhanova, O.S., Parfyonova, Y.V., 2009. Regulation of arterial remodeling and angiogenesis by urokinase-type plasminogen activator. Can. J. Physiol. Pharmacol. 87, 231-251.

Uysal, K.T., Wiesbrock, S.M., Marino, M.W., Hotamisligil, G.S., 1997. Protection from obesity-insulin resistance in mice lacking TNF- $\alpha$ function. Nature 389, 610-614.

Van Hinsbergh, V.W., Engelse, M.A., Quax, P.H., 2006. Pericellular proteases in angiogenesis and vasculogenesis. Arterioscler. Thromb. Vasc. Biol. 26, 716-728.

Varzaneh, F.E., Shillabeer, G., Wong, K.L., Lau, D.C., 1994. Extracellular matrix components secreted by microvascular endothelial cells stimulate preadipocyte differentiation in vitro. Metabolism 43, 906-912.

Vázquez, F., Hastings, G., Ortega, M.A., Lane, T.F., Oikemus, S., Lombardo, M., IruelaArispe, M.L., 1999. METH-1, a human ortholog of ADAMTS-1, and METH-2 are members of a new family of proteins with angio-inhibitory activity. J. Biol. Chem. 274, 23349-23357. 
Veikkola, T., Jussila, L., Makinen, T., Karpanen, T., Jeltsch, M., Petrova, T.V., Kubo, H., Thurston, G., McDonald, D.M., Achen, M.G., Stacker, S.A., Alitalo, K., 2001. Signalling via vascular endothelial growth factor receptor-3 is sufficient for lymphangiogenesis in transgenic mice. EMBO J., 20, 1223-1231.

Voros, G., Maquoi, E., Collen, D., Lijnen, H.R., 2003. Differential expression of plasminogen activator inhibitor-1, tumor necrosis factor- $\alpha$, TNF- $\alpha$ converting enzyme and ADAMTS family members in murine fat territories. Biochem. Biophys. Acta 1625, $36-42$.

Voros, G., Maquoi, E., Demeulemeester, D., Clerx, N., Collen, D., Lijnen, H.R., 2005. Modulation of angiogenesis during adipose tissue development in murine models of obesity. Endocrinology 146, 4545-4554.

Voros, G., Lijnen, H.R., 2006. Deficiency of thrombospondin-1 in mice does not affect adipose tissue development. J. Thromb. Haemost. 4, 277-278.

Weidmer, K.M., Hartmann, G., Naldini, L., Comoglio, P.M., Sachs, M., Fonatsch, C., Rieder H., Birchmeier, W., 1993. Molecular characteristics of HGF-SF and its role in cell motility and invasion. Exs 65, 311-328.

Wolfsberg, T.G., Straight, P.D., Gerena, R.L., Huovila, A.P., Primakoff, P., Myles, D.G., White, J.M., 1995. ADAM, a widely distributed and developmentally regulated gene family encoding membrane proteins with a disintegrin and metalloproteinase domain. Dev. Biol. 169, 378-383.

Zhang, Q.X., Magovern, C.J., Mack, C.A., Budenbender, K.T., Ko, W., Rosengart, T.K., 1997. Vascular endothelial growth factor is the major angiogenic factor in omentum: mechanism of the omentum-mediated angiogenesis. J. Surg. Res. 67, 147-154.

Zhang, Y., Deng, Y., Luther, T., Muller, M., Ziegler, R., Waldherr, R., Stern, D.M., Nawroth, P.P., 1994. Tissue factor controls the balance of angiogenic and antiangiogenic properties of tumor cells in mice. J. Clin. Invest. 94, 1320-1327.

Zuk, P.A., Zhu, M., Mizuno, H., Huang, J., Futrell, J.W., Katz, A.G., Benhaim, P., Lorenz H.P., Hedrick, M.H., 2001. Multilineage cells from human adipose tissue: implications for cell-based therapies. Tissue Eng. 7, 211-228. 